\title{
Cholesterol, Triglyceride, and Phospholipid Content of Intima, Media, and Atherosclerotic Fatty Streak in Human Thoracic Aorta*
}

\author{
William Insull, Jr., $\dagger$ and Glenn E. Bartsch $\ddagger$ \\ (From the Department of Medicine and Division of Biometry, University Hospitals and \\ Western Reserve University, Cleveland, Ohio)
}

The importance of lipids in the pathogenesis of atherosclerosis in man remains obscure, although the accumulation of lipids has long been acknowledged as closely associated with the lesions of the disease. The hypothesis that gross fatty streak lesions occur early in the sequence of pathogenesis provides a significant guide to the study of this disease $(1,2)$. Comprehensive knowledge about the lipids of the fatty streak lesions would form a firm basis for comparative study of the role lipids play in potentially precursive and successive lesions. At present, the characterization of fatty streak lipids, including their distribution and concentration in arterial tissue, is incomplete. This is due primarily to differences among the published studies in classification of the lesions, methods of tissue sampling, and choice of normal tissue specimens for control analyses. Few analyses have specifically distinguished the lipids of normal intima, normal media, and the fatty streak lesions of atherosclerosis (3-6).

This paper reports analyses of cholesterol, phospholipid, and triglyceride in the fatty streak lesions and grossly normal tissues from thoracic aortas of a homogenous group of 11 male subjects and a heterogenous group of 10 subjects (four male and six female). Significant correlations among the concentrations of these lipids in arterial tissues are described for the first time. The compositions of fatty acids from the cholesterol esters and tri-

\footnotetext{
* Submitted for publication July 12, 1965 ; accepted December 16, 1965.

Supported by U. S. Public Health Service grants H-5284, 5 POL HE 06304, GM T1-17, and GM 12302.

+ Address requests for reprints to Dr. William Insull, Dept. of Medicine, Western Reserve University School of Medicine, Cleveland, Ohio 44106.

$¥$ Present address: Department of Biostatistics, School of Public Health, University of Minnesota, Minneapolis, Minn.
}

glycerides of these specimens will be reported separately.

\section{Methods}

Methods of analysis. The thoracic aortas were obtained at autopsy within 20 hours of death. Tissues were stored by freezing in physiological saline solution at $-15^{\circ} \mathrm{C}$ until dissection. The extent of atherosclerosis was estimated by unaided visual inspection. Representative blocks of tissue were taken for histological examination. Tissue specimens for chemical analysis were obtained by semimicrodissection with ophthalmologic surgical instruments at 10 to $20 \times$ magnification and were restricted to one type of tissue as much as possible. Preliminary study showed that intima could be separated from media along a plane of cleavage in the media immediately adjacent to the internal elastic lamina. Precautions were taken to avoid contamination of tissue samples by lipid droplets from periadventitial adipose tissue during dissection. Dissecting instruments were kept free of lipid to avoid cross-contamination of the specimens. Tissues were kept moistened with physiological saline solution to avoid drying. Extensive samples of normal intima, free of gross lesions on inspection at $20 \times$ magnification, were obtained from the anterior wall of the aorta adjacent to the lesions. Intimal fatty streak lesions were identified as yellowish, slightly raised areas, which, at $30 \times$ magnification, appeared as grapelike clusters of yellowish, opaque spots covered by a delicate transparent membrane. All the fatty streak lesions were confined to the intima, as the underlying internal elastic lamina was grossly intact and the media was of normal color and consistency. The lesions were isolated by incising their peripheral edge and peeling them off the media. To obtain sufficient tissue in each aorta, we pooled individual lesions. About half of the specimens of intima and fatty streak lesions contained internal elastic lamina and a trace of medial fibers. Fatty-fibrous plaques were identified by the presence of a pale gray, translucent, tough membrane over a yellow fatty deposit. Media was sampled from the anterior wall in areas of normal intima and excluded adventitia and internal elastic lamina.

The dissected tissue was carefully blotted, weighed (range, 75 to $700 \mathrm{mg}$ per specimen), and homogenized with physiological saline or methanol in an Omni-mixer 
blender. Lipid was extracted from the homogenate by over $20 \mathrm{vol}$ of a chloroform-methanol mixture, 2:1. This extraction procedure removed all lipid, as preliminary studies showed that alkali digestion of extracted tissue failed to recover additional fatty acids. The extract was evaporated to dryness with $3 \mathrm{ml}$ of isooctane : butanol $(1: 1)$ and sufficient absolute ethanol to remove the water. Lipids were extracted from the residue with chloroform. Preliminary study showed adequate recovery of phospholipids by avoiding the loss of lysolecithin occurring when a chloroform-methanol extract is washed with water (7). Lipids were separated into a neutral fraction and a polar phospholipid fraction by chromatography on silicic acid by eluting with chloroform and methanol, respectively (8). Neutral lipids were chromatographed on magnesium silicate and yielded fractions of hydrócarbons, esterified cholesterol, triglyceride, and free cholesterol (9). The efficiency of these separations was checked periodically by chromatography of pure lipid standards. Preliminary study showed greater than $95 \%$ recovery of lipid from the silicic acid and magnesium silicate columns. The lipid fractions were analyzed in duplicate: cholesterol by the method of Abell, Levy, Brodie, and Kendall (10) ; triglyceride, by the method of Carlson and Wadström (11); and phospholipid phosphorus by the method of Bartlett (12), as adapted to

TABLE I

Descriptions of specimens of thoracic aorta

\begin{tabular}{|c|c|c|c|c|c|c|c|}
\hline Aorta no. & Age & Sex & Race* & Autopsy diagnosis & 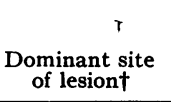 & $\begin{array}{l}\text { Propor- } \\
\text { tion of } \\
\text { site in- } \\
\text { volved }\end{array}$ & Type of lesion \\
\hline Group I & years & & & & & $\%$ & \\
\hline 1 & 25 & M & $\mathrm{W}$ & Auto accident & Intercostal & 15 & Fatty streaks \\
\hline 2 & 31 & $\mathbf{M}$ & $\dot{W}$ & Myocardial infarction & Intercostal & 90 & Fatty streaks \\
\hline 3 & 33 & $\mathbf{M}$ & W & Gunshot & General & 15 & Fatty streaks \\
\hline 4 & 34 & $\mathbf{M}$ & $\mathrm{H}$ & $\begin{array}{l}\text { Pneumonia, alcoholism, } \\
\text { cirrhosis }\end{array}$ & Posterior & 15 & Fatty streaks \\
\hline 5 & 38 & M & $W$ & Subarachnoid hemorrhage & Posterior & 30 & Fatty streaks \\
\hline 6 & 38 & M & W & Drowning & Intercostal & 30 & Fatty streaks \\
\hline 7 & 41 & $\mathbf{M}$ & $\mathrm{N}$ & Coronary occlusion & Intercostal & 5 & $\begin{array}{l}\text { Fatty streaks and two } \\
\text { fibrous plaques }\end{array}$ \\
\hline 8 & 42 & $\mathbf{M}$ & W & Alcoholism, fatty liver & Anterior & $<1$ & Fatty streaks \\
\hline 9 & 42 & $\mathbf{M}$ & W & Pneumonia & Intercostal & 50 & Fatty streaks \\
\hline 10 & 43 & $\mathbf{M}$ & W & $\begin{array}{l}\text { Chronic hypertension and } \\
\text { coronary a therosclerosis }\end{array}$ & Intercostal & 95 & Fatty streaks \\
\hline 11 & 44 & M & $\mathrm{N}$ & Coronary occlusion & Intercostal & 25 & $\begin{array}{l}\text { Fatty streaks and two } \\
\text { fibrous plaques }\end{array}$ \\
\hline \multicolumn{8}{|l|}{ Group II } \\
\hline 12 & 46 & $\mathbf{M}$ & W & $\begin{array}{l}\text { Cerebral hemorrhage, } \\
\text { cirrhosis }\end{array}$ & General & $\begin{array}{r}60 \\
1\end{array}$ & $\begin{array}{l}\text { Fatty streaks and } \\
\text { fibrous plaques }\end{array}$ \\
\hline 13 & 48 & M & W & Lymphosarcoma & Intercostal & $\begin{array}{r}40 \\
<1\end{array}$ & $\begin{array}{l}\text { Fatty streaks and } \\
\text { fibrous plaques }\end{array}$ \\
\hline 14 & 54 & M & $\mathrm{N}$ & $\begin{array}{l}\text { Metastatic carcinoma } \\
\text { of stomach }\end{array}$ & General & $\begin{array}{l}10 \\
15\end{array}$ & $\begin{array}{l}\text { Fatty streaks and } \\
\text { fibrous plaques }\end{array}$ \\
\hline 15 & 60 & M & W & $\begin{array}{l}\text { Myocardial infarction, } \\
\text { carcinoma of duodenum }\end{array}$ & General & $\begin{array}{r}5 \\
15\end{array}$ & $\begin{array}{l}\text { Fatty streaks and } \\
\text { fibrous plaques }\end{array}$ \\
\hline 16 & 35 & $\mathrm{~F}$ & $N$ & Acute myocarditis & Posterior & 50 & Fatty streaks \\
\hline 17 & 37 & $\mathrm{~F}$ & W & $\begin{array}{l}\text { Myocardial infarction, } \\
\text { diabetes mellitus }\end{array}$ & Posterior & $\begin{array}{r}50 \\
5\end{array}$ & $\begin{array}{l}\text { Fatty streaks and } \\
\text { fibrous plaques }\end{array}$ \\
\hline 18 & 41 & $\mathrm{~F}$ & $\mathrm{~N}$ & Subarachnoid hemorrhage & Intercostal & 50 & Fatty streaks \\
\hline 19 & 46 & $\mathrm{~F}$ & W & $\begin{array}{l}\text { Metastatic carcinoma of } \\
\text { breast }\end{array}$ & General & $\begin{array}{l}15 \\
10\end{array}$ & $\begin{array}{l}\text { Fatty streaks and } \\
\text { fibrous plaques }\end{array}$ \\
\hline 20 & 52 & $\mathbf{F}$ & $\mathrm{N}$ & Pneumonia, nephrosclerosis & Posterior & 40 & Fatty streaks \\
\hline 21 & 63 & $\mathrm{~F}$ & $W$ & Lymphosarcoma & General & 25 & $\begin{array}{l}\text { Fatty streaks and } \\
\text { fibrous plaques }\end{array}$ \\
\hline
\end{tabular}

$* \mathrm{~W}=$ Caucasian $; \mathrm{H}=$ Hawaiian, $\mathrm{N}=$ Negro.

† Intercostal = aortic surface bounded by orifices of intercostal arteries; posterior, anterior = respective halves of aortic surface. 
TABLE II

Content of total cholesterol and proportion esterified in aortic tissues

\begin{tabular}{|c|c|c|c|c|c|c|}
\hline \multirow[b]{2}{*}{ Aorta no. } & \multicolumn{2}{|c|}{ Media } & \multicolumn{2}{|c|}{ Intima } & \multicolumn{2}{|c|}{ Fatty streak } \\
\hline & $\begin{array}{c}\text { Total } \\
\text { cholesterol }\end{array}$ & $\begin{array}{l}\text { Per cent } \\
\text { esterified }\end{array}$ & $\begin{array}{c}\text { Total } \\
\text { cholesterol }\end{array}$ & $\begin{array}{l}\text { Per cent } \\
\text { esterified }\end{array}$ & $\begin{array}{c}\text { Total } \\
\text { cholesterol }\end{array}$ & $\begin{array}{l}\text { Per cent } \\
\text { esterified }\end{array}$ \\
\hline \multicolumn{7}{|l|}{ Group I } \\
\hline $\begin{array}{r}1 \\
2 \\
3 \\
4 \\
5 \\
6 \\
7 \\
8 \\
9 \\
10 \\
11\end{array}$ & $\begin{array}{l}2.32 \\
2.72 \\
0.67 \\
4.40 \\
3.20 \\
4.80 \\
1.76 \\
3.04 \\
4.60 \\
5.30 \\
1.87\end{array}$ & $\begin{array}{r}27.0 \\
26.0 \\
55.3 \\
32.0 \\
31.3 \\
33.0 \\
14.8 \\
7.8 \\
37.0 \\
30.0 \\
25.0\end{array}$ & $\begin{array}{l}5.10 \\
2.60 \\
4.70 \\
3.10 \\
3.50 \\
2.80 \\
2.30 \\
1.56 \\
3.60 \\
1.09 \\
1.40\end{array}$ & $\begin{array}{l}47.0 \\
53.8 \\
51.0 \\
45.0 \\
45.7 \\
57.2 \\
47.8 \\
53.8 \\
55.5 \\
43.1 \\
53.6\end{array}$ & $\begin{array}{r}18.2 \\
21.9 \\
21.0 \\
20.5 \\
10.3 \\
9.6 \\
19.6 \\
\\
15.3 \\
10.7 \\
15.2\end{array}$ & $\begin{array}{l}73.6 \\
79.0 \\
60.0 \\
59.6 \\
50.5 \\
73.0 \\
80.1 \\
\\
64.1 \\
84.1 \\
82.3\end{array}$ \\
\hline \multicolumn{7}{|l|}{ Group II } \\
\hline $\begin{array}{l}12 \\
13 \\
14 \\
15 \\
16 \\
17 \\
18 \\
19 \\
20 \\
21\end{array}$ & $\begin{array}{l}2.98 \\
3.28 \\
2.65 \\
\\
2.55 \\
3.70 \\
2.02 \\
7.04 \\
3.08 \\
3.00\end{array}$ & $\begin{array}{c}40.3 \\
29.6 \\
28.0 \\
\\
20.4 \\
29.6 \\
25.6 \\
37.0 \\
15.3 \\
3.34\end{array}$ & $\begin{array}{l}4.00 \\
2.02 \\
7.00 \\
8.70 \\
3.48 \\
4.40 \\
2.50 \\
4.53 \\
6.69 \\
5.00\end{array}$ & $\begin{array}{l}70.5 \\
59.5 \\
63.0 \\
52.0 \\
40.6 \\
66.0 \\
48.0 \\
59.5 \\
61.0 \\
74.0\end{array}$ & $\begin{array}{l}26.9 \\
13.5 \\
23.6 \\
74.5 \\
30.6 \\
22.4 \\
16.4 \\
35.4 \\
37.4 \\
35.2\end{array}$ & $\begin{array}{l}45.4 \\
65.2 \\
37.0 \\
41.6 \\
75.2 \\
49.2 \\
67.7 \\
62.0 \\
64.0 \\
78.0\end{array}$ \\
\hline $\begin{array}{l}\text { Mean, group I } \\
\text { Mean, group II } \\
\text { Difference: p }\end{array}$ & $\begin{array}{l}3.15 \\
3.37 \\
\text { NS }\end{array}$ & $\begin{array}{l}29.0 \\
28.8 \\
\mathrm{NS}\end{array}$ & $\begin{array}{r}2.89 \\
4.83 \\
<0.05\end{array}$ & $\begin{array}{r}50.3 \\
59.4 \\
<0.05\end{array}$ & $\begin{array}{r}16.2 \\
31.6 \\
<0.05\end{array}$ & $\begin{array}{l}70.6 \\
58.5 \\
\text { NS }\end{array}$ \\
\hline
\end{tabular}

the submicrodetermination of phosphorus by the use of microchemical glassware and spectrophotometer cuvettes, and a low phosphorus hydrogen peroxide reagent 1 (7). The optical density of the final solution follows Beer's law for 0.05 and $0.6 \mathrm{mg}$ phosphorus. Total phospholipid was estimated by multiplying the lipid phosphorus by the factor 25. Glyceride was expressed as weight equivalent of tristearin. All analyses have been expressed as the average in milligrams lipid per gram wet weight tissue. Group II tissues were analyzed before those of group I; otherwise, the order of analysis was random. Due to loss in the laboratory, analyses were occasionally not obtained. The data of the two groups of tissue have been analyzed separately.

To compare the tissue lipids within a single aorta, the differences in the concentration of each lipid class between the various tissues were calculated. For each group of aortas the means of these various differences were calculated. These mean differences have been compared to zero by means of Student's $t$ test and have been considered significant if $\mathrm{p}<0.05$ (13). Correlation coefficients have been calculated for each group to assess the presence of associations among the concentrations of lipids. Partial correlations adjusted for age were also calculated. The correlation coefficients of the two groups were combined by using the zeta transformation. Cor-

$190 \%$ hydrogen peroxide, FMC Corp., New York, N. Y. relation coefficients were interpreted to be significant if they were different from zero at the $5 \%$ level. Calculations were performed with the aid of an electronic computer.

Characterization of tissue specimens. Tissue specimens were assigned to two groups (Table I). Group I was designed to be homogeneous. All 11 subjects were male, and there were two Negroes; their age averaged 37.3 years with a range of 25 to 44 ; all had died suddenly outside the hospital after being in reasonably good health; the atherosclerotic lesions of the thoracic aorta were almost exclusively of the fatty streak type. Group II was designed to encompass a broader experience. Both sexes were included, with four males (one Negro) and six females (three Negroes); the range of age was wider, 37 to 63 years, with an average of 48.2 years. These individuals had died in the hospital of various chronic diseases, and their lesions of atherosclerosis included streaks and fatty-fibrous plaques. Diabetes was diagnosed in one subject, No. 17. The average age of group II was not significantly different from that of group I. In group I the lesions of atherosclerosis were of limited extent and were exclusively fatty ștreaks except for aortas 7 and 11, which had small fatty-fibrous plaques. The lesions were usually distributed exclusively on the posterior half of the aorta and were frequently confined to the area bounded by the orifices of the intercostal arteries. Lesions covered an average of $8 \%$ of the entire intimal surface with a range of $<1$ to $15 \%$. The two 
lesions of aorta 8 provided insufficient material for analysis. In the aortas of group II the lesions were more extensive and usually included fibrous plaques. With fatty streaks predominating, both kinds of lesions combined covered an average of $26 \%$ of the entire surface with a range of 6 to $61 \%$. On examination with a dissecting microscope, the intensity of fat deposition in the fatty streak lesions, while uniform in each aorta, varied among the aortas. Some aortas had only widely scattered stippling of the raised streak lesions by opaque, spotty accumulations of lipid. At the extreme, there was complete opacification of the entire lesions by contiguous lipid aggregates. On microscopic examination of frozen sections stained with oil red $O$, less than half the grossly normal intimae were free of lipid. In most, finely dispersed lipid was seen in cells along the intimal side of the internal elastic lamina, whereas in a few, finely dispersed lipid was observed throughout the intima. The intimal fatty streaks contained both fine dispersions and confluent accumulations of lipid throughout the full thickness of the intimae without crystal-clefts or inflammatory cells. These lesions were almost entirely confined to the intima; the media showed only occasionally finely dispersed lipid adjacent to the intimal fatty streak.

\section{Results}

Comparisons of lipid content. The content of total and esterified cholesterol in the various areas is presented in Table II, and the content of total phospholipid and triglyceride in Table III. Significant differences in the content of lipids occurred between the groups of aortas and among the tissues within the aortas.

The intimae of group I had a lower content of total cholesterol and a lesser per cent of it esterified than those of group II (Table II). The concentration of intimal esterified cholesterol in group I (average, $1.5 \mathrm{mg}$ per $\mathrm{g}$ ) was significantly lower $(p<0.01)$ than that in group II (average, 2.9 $\mathrm{mg}$ per $\mathrm{g}$ ), whereas there was no significant difference between the concentrations of the intimal free cholesterols in the two groups, group I averaging 1.5 , and group II averaging 1.9. The fatty streaks in the aortas of group II had a significantly higher content of free, esterified, and total cholesterols and triglyceride than those of group I $(p<0.05$, Tables II and III). The per cent of cholesterol esterified in the fatty streaks was not significantly different between the groups. The average concentrations of medial cholesterol and triglyceride of the two groups were not significantly different.

TABLE III

Content of total phospholipid and triglyceride in aortic tissues

\begin{tabular}{|c|c|c|c|c|c|c|}
\hline \multirow[b]{2}{*}{ Aorta no. } & \multicolumn{3}{|c|}{ Phospholipid } & \multicolumn{3}{|c|}{ Triglyceride } \\
\hline & Media & Intima & Fatty streak & Media & Intima & Fatty streak \\
\hline \multirow{2}{*}{\multicolumn{7}{|c|}{ Group I }} \\
\hline & & & & & & \\
\hline 1 & 4.33 & 6.00 & 6.25 & 0.18 & 2.30 & 1.50 \\
\hline 2 & 4.02 & 3.71 & 5.56 & 0.14 & 0.66 & 0.33 \\
\hline 3 & 5.23 & 3.91 & 7.47 & 0.22 & 0.83 & 0.93 \\
\hline 4 & 3.79 & 3.15 & & 0.38 & 0.79 & 1.10 \\
\hline 5 & 8.39 & 4.41 & 6.14 & 0.25 & 0.51 & 0.45 \\
\hline 6 & & 3.39 & 3.96 & 0.45 & 0.86 & 1.04 \\
\hline 7 & 6.50 & & 5.50 & 0.11 & 0.37 & 0.23 \\
\hline 8 & 3.84 & 1.67 & & 0.30 & 0.83 & \\
\hline 9 & 3.42 & 4.04 & 4.69 & 0.54 & 0.98 & 1.20 \\
\hline 10 & 3.86 & 1.72 & 1.96 & 0.47 & 0.82 & 0.93 \\
\hline 11 & 5.50 & 1.61 & 2.41 & 0.35 & 1.00 & 1.50 \\
\hline \multicolumn{7}{|l|}{ Group II } \\
\hline 12 & & & & 0.44 & 1.10 & 2.90 \\
\hline 13 & & & & 0.78 & 0.66 & 0.59 \\
\hline 14 & & & & 0.18 & $\begin{array}{l}1.80 \\
0.50\end{array}$ & 1.40 \\
\hline 15 & & & & 0.49 & $\begin{array}{r}0.50 \\
180\end{array}$ & $\begin{array}{l}3.60 \\
1.80\end{array}$ \\
\hline $\begin{array}{l}16 \\
17\end{array}$ & & & & 0.44 & $\begin{array}{l}1.00 \\
1.28\end{array}$ & $\begin{array}{l}1.00 \\
1.45\end{array}$ \\
\hline $\begin{array}{l}17 \\
18\end{array}$ & & & & 0.15 & 0.35 & 1.23 \\
\hline 19 & & & & 0.58 & 1.05 & 1.55 \\
\hline 20 & 3.11 & 3.07 & 8.96 & 0.19 & 1.89 & 1.16 \\
\hline 21 & 2.48 & 1.06 & 7.83 & 0.17 & 1.17 & 0.97 \\
\hline Mean, group I & 4.89 & 3.36 & 4.88 & 0.31 & 0.90 & 0.92 \\
\hline Mean, group II & & & & 0.38 & 1.16 & 1.67 \\
\hline Difference: $p$ & & & & NS & NS & $<0.05$ \\
\hline
\end{tabular}


TABLE IV

Average differences between tissues within an acrta in concentrations of total cholesterol, free cholesterol, esterified cholesterol, phospholipid, and triglyceride

\begin{tabular}{|c|c|c|c|c|}
\hline \multirow[b]{3}{*}{ Lipid } & \multicolumn{4}{|c|}{ Average difference in concentrations of specified lipid between tissues by aortic group } \\
\hline & \multicolumn{2}{|c|}{ Fatty streak minus intima } & \multicolumn{2}{|c|}{ Media minus intima } \\
\hline & Group I & Group II & Group I & Group II \\
\hline $\begin{array}{l}\text { Total cholesterol } \\
\text { Free cholesterol } \\
\text { Esterified cholesterol } \\
\text { Phospholipid } \\
\text { Triglyceride }\end{array}$ & $\begin{array}{l}+13.2 \ddagger(10)^{*} \\
+3.3 \ddagger(10) \\
+9.7 \ddagger(10) \\
+1.2 \dagger(8) \\
0.0(10)\end{array}$ & $\begin{array}{l}+26.8 \ddagger(10) \\
+12.0 \ddagger(10) \\
+14.7 \ddagger(10) \\
+0.5(10)\end{array}$ & $\begin{array}{l}+0.27(11) \\
+0.81 \dagger(11) \\
-0.54 \dagger(11) \\
+1.35 \dagger(9) \\
-0.59 \ddagger(11)\end{array}$ & $\begin{array}{l}-0.92(9) \\
+0.68 \dagger(9) \\
-1.68 \ddagger(9) \\
-0.85 \ddagger(9)\end{array}$ \\
\hline
\end{tabular}

* Figure in parentheses is the number of intra-aortic comparisons.

$\dagger$ Significantly different from the value zero with $\mathrm{p} \leqq 0.05$.

¥ Significantly different from the value zero with $\mathrm{p} \leqq 0.01$.

The comparisons of lipid content between fatty streaks and intima and between media and intima within each aorta are summarized as the average differences in Table IV. The fatty streaks had a significantly higher content of total cholesterol, free cholesterol, and esterified cholesterol than the normal intimae in both groups of aortas. In group I the phospholipid content was significantly greater in the fatty streaks than in the intimae. There was no evidence that the triglyceride content of the fatty streak differed from that of the intima in either group. Whereas the concentration of the total cholesterol of the fatty streaks averaged about fivefold higher than that of their normal intimae, the phospholipid of the streaks averaged only about one-third higher that that of their normal intimae. The lowest total and esterified cholesterol concentrations in any fatty streak (aortas 6 and 5, respectively) were as high or higher than the total and esterified cholesterol in every normal intima. The lowest concentration of free cholesterol in the fatty streaks (aorta 10) was exceeded by the free cholesterol in eight normal intimae (Tables II and III). The cholesterol content of the mediae differed from that of normal intimae by having significantly more free cholesterol and less esterified cholesterol, although the total cholesterol of the two tissues was not significantly different (Table IV). The per cent of cholesterol esterified was higher in the intima than in the media, averaging, respectively, $54.5 \%$ and $28.9 \%$ for all the aortas. Only one media had more than $40.3 \%$ cholesterol esterified (aorta 3 with $55.3 \%$ ), whereas the lowest per cent esterified in an intima was $40.6 \%$ (aorta 16 ). The phospholipid content of the media was significantly higher than that of the intima, and that of the triglyceride was lower.

Correlations between lipids and age and between lipids. The correlation coefficients between concentrations of different lipids of the aortic tissues and age were examined to determine the possibility of concurrent effects of age upon lipid interrelationships (Table V). In the mediae there was no evidence of an association between the concentration of any lipid and age, whereas in the intimae

TABLE V

Correlations between age and concentrations of different lipids of aortic tissues

\begin{tabular}{|c|c|c|c|c|c|c|}
\hline \multirow[b]{3}{*}{ Lipid } & \multicolumn{6}{|c|}{ Correlation coefficient of age with concentrations of specified lipid by tissue and aortic group } \\
\hline & \multicolumn{2}{|c|}{ Media } & \multicolumn{2}{|c|}{ Intima } & \multicolumn{2}{|c|}{ Fatty streak } \\
\hline & Group I & Group II & Group I & Group II & Group I & Group II \\
\hline $\begin{array}{l}\text { Free cholesterol } \\
\text { Esterified cholesterol } \\
\text { Total cholesterol } \\
\text { Phospholipid } \\
\text { Triglyceride }\end{array}$ & $\begin{array}{l}0.34(11)^{*} \\
0.15(11) \\
0.29(11) \\
0.11(10) \\
0.51(11)\end{array}$ & $\begin{array}{r}-0.05(9)^{*} \\
0.04(9) \\
-0.01(9) \\
-0.39(9)\end{array}$ & $\begin{array}{l}-0.79 \ddagger(11) \\
-0.70 \dagger(11) \\
-0.76 \ddagger(11) \\
-0.79 \ddagger(10) \\
-0.57 \quad(11)\end{array}$ & $\begin{array}{c}0.41(10) \\
0.72 \dagger(10) \\
0.64 \dagger(10) \\
-0.10 \quad(10)\end{array}$ & $\begin{array}{lr}-0.48 & (10) \\
-0.36 & (10) \\
-0.52 & (10) \\
-0.69 \dagger & (9) \\
-0.06 & (10)\end{array}$ & $\begin{array}{l}0.47(10) \\
0.46(10) \\
0.54(10) \\
0.14(10)\end{array}$ \\
\hline
\end{tabular}

* Figures in parentheses indicate the number of observations.

$\dagger$ Significant at $\mathbf{0 . 0 5}$.

$\ddagger$ Significant at 0.01 . 
there was evidence of associations, as some of the coefficients of the two aortic groups had opposite signs. In group I the concentrations of free, esterified, and total cholesterol were negatively associated $(p<0.05)$ with age; in group II these correlations were positive $(\mathrm{p}<0.05$ in 2 of 3 cases). In the fatty streak the correlations of the cholesterols with age were also observed to be negative in group I and positive in group II, but none was significant. In both intimae and fatty streaks of group I aortas the phospholipid was negatively correlated with age $(p<0.05)$. In all tissues there was insufficient evidence of an association between triglyceride concentration and age. The partial correlations between the lipid concentrations removing the effect of age were not appreciably different from their counterpart total correlations and are not reported here.

Coefficients of correlation among lipids were examined, and patterns of association among the concentrations in normal and diseased tissues were sought. The correlations of free and esterified cholesterol with total cholesterol are not presented, since the high incidence of significant correlations among them merely reflects the relationship between a major part and a whole. For convenience, these correlations are considered in the following three classes.

$A$ ) Correlations between the concentrations of different lipids writhin aortic tissues. Significant correlations occurred within each aortic tissue (Table VI). In the media, significant positive correlations occurred between the free and esterified cholesterols and between triglyceride and free, esterified, and total cholesterols. In the intima, significant positive correlations occurred between free and esterified cholesterols and between phospholipid and free, esterified, and total cholesterols. In the fatty streak, free cholesterol correlated positively with phospholipid and triglyceride. Some patterns of association appeared. Free and esterified cholesterols showed positive associations, strong in the media and intima $(\mathrm{p}<0.01)$ but only moderate in the fatty streak $(p>0.05)$. Phospholipid showed positive associations with each of the cholesterols, strong in the intima $(p<0.01)$ and moderate in the fatty streak $(p>0.05)$, whereas in the media these associations were negative. Triglyceride and the cholesterols showed positive associations, strong in the media ( $p<$ 0.01 ) but only moderate in the intima and fatty streak $(p>0.05)$. The triglyceride and phospholipid showed no association in any of the tissues.

$B$ ) Correlations between the concentrations of a single lipid in different aortic tissues. Of the significant correlations, all but one were observed between lipids of the intima and the fatty streak (Table VII). The free and total cholesterols and phospholipid in the fatty streak were positively associated with the corresponding lipids in the in-

TABLE VI

Correlations between the concentrations of different lipids within aortic lissues

\begin{tabular}{|c|c|c|c|c|c|c|c|c|c|}
\hline \multirow[b]{3}{*}{ Lipids } & \multicolumn{9}{|c|}{ Correlation coefficients between concentrations of specified lipids by tissue and aortic group } \\
\hline & \multicolumn{3}{|c|}{ Media } & \multicolumn{3}{|c|}{ Intima } & \multicolumn{3}{|c|}{ Fatty streak } \\
\hline & Group I & Group II & $\begin{array}{l}\text { Com- } \\
\text { bined }\end{array}$ & Group I & Group II. & $\begin{array}{l}\text { Com- } \\
\text { bined }\end{array}$ & Group I & Group II & $\begin{array}{l}\text { Com- } \\
\text { bined }\end{array}$ \\
\hline $\begin{array}{l}\text { Free and } \\
\text { ester cholesterol }\end{array}$ & $0.76 \ddagger(11)^{*}$ & $0.87 \ddagger(9)$ & $0.82 \ddagger$ & $0.92 \ddagger(11)$ & $0.68 \dagger(10)$ & $0.84 \ddagger$ & $0.18 \quad(10)$ & $0.51(10)$ & 0.35 \\
\hline $\begin{array}{l}\text { Phospholipid and } \\
\text { free cholesterol }\end{array}$ & $-0.43(10)$ & & & $0.91 \ddagger(10)$ & & & $0.87 \ddagger(9)$ & & \\
\hline $\begin{array}{l}\text { Phospholipid and } \\
\text { ester cholesterol }\end{array}$ & $-0.33 \quad(10)$ & & & $0.89 \ddagger(10)$ & & & $0.23(9)$ & & \\
\hline $\begin{array}{l}\text { Phospholipid and } \\
\text { total cholesterol }\end{array}$ & $-0.42 \quad(10)$ & & & $0.92 \ddagger(10)$ & & & $0.56 （ 9)$ & & \\
\hline $\begin{array}{l}\text { Triglyceride and } \\
\text { free cholesterol }\end{array}$ & $0.69 \dagger(11)$ & $0.45 \quad(9)$ & $0.60 \ddagger$ & $0.51 \quad(11)$ & $0.12 \quad(10)$ & 0.34 & $-0.01 \quad(10)$ & $0.82 \ddagger(10)$ & $0.52 \dagger$ \\
\hline $\begin{array}{l}\text { Triglyceride and } \\
\text { ester cholesterol }\end{array}$ & $0.80 \ddagger(11)$ & $0.45 \quad(9)$ & $0.68 \ddagger$ & $0.47 \quad(11)$ & $0.32 \quad(10)$ & 0.40 & $-0.17 \quad(10)$ & $0.37 \quad(10)$ & 0.11 \\
\hline $\begin{array}{l}\text { Triglyceride and } \\
\text { total cholesterol }\end{array}$ & $0.78 \ddagger(11)$ & $0.46 \quad(9)$ & $0.67 \ddagger$ & 0.50 & $0.26 \quad(10)$ & 0.40 & $-0.14 \quad(10)$ & $0.72 \dagger(10)$ & 0.37 \\
\hline $\begin{array}{l}\text { Triglyceride and } \\
\text { phospholipid }\end{array}$ & $-0.45 \quad(10)$ & & & $0.53 \quad(10)$ & & & $-0.32 \quad(9)$ & & \\
\hline
\end{tabular}

* Figures in parentheses indicate the number of observations. † Significant at 0.05 . 
TABLE VII

Correlations between the concentrations of a single lipid in different aortic tissues

\begin{tabular}{|c|c|c|c|c|c|c|}
\hline \multirow{4}{*}{$\frac{\text { Tissues }}{\begin{array}{c}\text { Intima and } \\
\text { fatty streak }\end{array}}$} & \multirow{3}{*}{$\frac{\text { Aortic group }}{\text { I }}$} & \multicolumn{5}{|c|}{$\begin{array}{l}\text { Correlation coefficients between the concentrations of a lipid in } \\
\text { specified pairs of aortic tissues by aortic group }\end{array}$} \\
\hline & & \multirow{2}{*}{$\begin{array}{c}\begin{array}{c}\text { Free } \\
\text { cholesterol }\end{array} \\
0.68+(10)^{*}\end{array}$} & $\begin{array}{c}\text { Esterified } \\
\text { cholesterol }\end{array}$ & $\begin{array}{c}\text { Total } \\
\text { cholesterol }\end{array}$ & \multirow{2}{*}{$\frac{\text { Phospholipid }}{0.81 \dagger(8)}$} & \multirow{2}{*}{$\begin{array}{c}\text { Triglyceride } \\
0.73 \dagger(10)\end{array}$} \\
\hline & & & $0.01 \quad(10)$ & $0.33 \quad(10)$ & & \\
\hline & $\stackrel{\text { II }}{\text { Combined }}$ & $\begin{array}{l}0.87 \ddagger(10) \\
0.79 \ddagger\end{array}$ & $\begin{array}{l}0.41 \quad(10) \\
0.22\end{array}$ & $\begin{array}{l}0.79 \ddagger(10) \\
0.61 \ddagger\end{array}$ & $0.81 \dagger$ & $\begin{array}{r}-0.21 \\
0.35\end{array}$ \\
\hline \multirow{2}{*}{$\begin{array}{l}\text { Intima and } \\
\text { media }\end{array}$} & I & $-0.45 \quad(11)$ & $0.004(11)$ & $-0.32 \quad(11)$ & $0.20 \quad(9)$ & $-0.01 \quad(11)$ \\
\hline & $\stackrel{\text { II }}{\text { Combined }}$ & $\begin{array}{r}0.12 \quad(9) \\
-0.22\end{array}$ & $\begin{array}{l}0.09 \\
0.04\end{array}$ & $\begin{array}{r}0.07 \quad(9) \\
-0.16\end{array}$ & 0.20 & $\begin{array}{l}-0.25(9) \\
-0.12\end{array}$ \\
\hline \multirow{2}{*}{$\begin{array}{l}\text { Fatty streak } \\
\text { and media }\end{array}$} & I & $-0.39 \quad(10)$ & $-0.63 \dagger(10)$ & $-0.58 \quad(10)$ & $0.29 \quad(8)$ & $0.51 \quad(10)$ \\
\hline & $\begin{array}{l}\text { II } \cdot \\
\text { Combined }\end{array}$ & $\begin{array}{r}0.40 \quad(9) \\
-0.03\end{array}$ & $\begin{array}{r}0.09 \quad(9) \\
-0.34\end{array}$ & $\begin{array}{r}0.38 \quad(9) \\
-0.17\end{array}$ & 0.29 & $\begin{array}{l}0.02(9) \\
0.30\end{array}$ \\
\hline
\end{tabular}

* Figures in parentheses indicate the number of observations.

† Significant at 0.05 .

\$ Significant at 0.01 .

tima. There was no evidence of an association between the esterified cholesterol in these two tissues. The combined correlation coefficient between triglycerides of the intima and fatty streak gave no evidence of an association. The correlations between the lipids of other pairs of tissues are small and have both positive and negative signs, which suggest the absence of relationships.

C) Correlations between the concentrations of different lipids in different aortic tissues. Only with the intima and fatty streak were any of these correlations significant. Since the medial lipids failed to correlate significantly with lipids of the intima and fatty streak, their correlations are not reported. The free and total cholesterols of the fatty streak correlate positively with free, esterified, and total cholesterol of the intima (Table VIII). The esterified cholesterol of the fatty streak does not appear to correlate with any intimal lipid. The phospholipid of the fatty streak

TABLE VIII

Correlations between the concentrations of different lipids in two different aortic tissues, intima and fatty streak

\begin{tabular}{|c|c|c|c|c|c|c|}
\hline & & \multicolumn{5}{|c|}{ Intimal lipids by aortic group } \\
\hline \multicolumn{2}{|c|}{$\begin{array}{l}\text { Fatty streak lipids } \\
\text { by aortic group }\end{array}$} & $\begin{array}{c}\text { Free } \\
\text { cholesterol }\end{array}$ & $\begin{array}{c}\text { Esterified } \\
\text { cholesterol }\end{array}$ & $\begin{array}{c}\text { Total } \\
\text { cholesterol }\end{array}$ & Phospholipid & Triglyceride \\
\hline $\begin{array}{l}\text { Free } \\
\quad \text { cholesterol }\end{array}$ & $\begin{array}{l}\text { Group I } \\
\text { Group II } \\
\text { Combined }\end{array}$ & $\begin{array}{l}0.68 \dagger(10)^{*} \\
0.87 \ddagger(10) \\
0.79 \ddagger\end{array}$ & $\begin{array}{l}0.63 \dagger(10) \\
0.65 \dagger(10) \\
0.68 \ddagger\end{array}$ & $\begin{array}{l}\text { C.67† (10) } \\
0.82 \ddagger(10) \\
0.76 \ddagger\end{array}$ & $0.42(9)$ & $\begin{array}{l}-0.004(10) \\
-0.21 \quad(10) \\
-0.11\end{array}$ \\
\hline $\begin{array}{l}\text { Esterified } \\
\text { cholesterol }\end{array}$ & $\begin{array}{l}\text { Group I } \\
\text { Group II } \\
\text { Combined }\end{array}$ & $\begin{array}{ll}0.01 & (10) \\
0.57 & (10) \\
0.32 & \end{array}$ & $\begin{array}{ll}0.01 & (10) \\
0.41 & (10) \\
0.22 & \end{array}$ & $\begin{array}{ll}0.01 & (10) \\
0.52 & (10) \\
0.29 & \end{array}$ & $0.07(9)$ & $\begin{array}{ll}0.10 & (10) \\
0.05 & (10) \\
0.08 & \end{array}$ \\
\hline $\begin{array}{l}\text { Total } \\
\text { cholesterol }\end{array}$ & $\begin{array}{l}\text { Group I } \\
\text { Group II } \\
\text { Combined }\end{array}$ & $\begin{array}{l}0.34(10) \\
0.85 \ddagger(10) \\
0.67 \ddagger\end{array}$ & $\begin{array}{l}0.31(10) \\
0.63 \dagger(10) \\
0.49 \dagger\end{array}$ & $\begin{array}{l}0.33(10) \\
0.79 \ddagger(10) \\
0.61 \ddagger\end{array}$ & $0.26 \quad(9)$ & $\begin{array}{rr}0.07 & (10) \\
-0.11 & (10) \\
-0.02 & \end{array}$ \\
\hline Phospholipid & $\begin{array}{l}\text { Group I } \\
\text { Group II } \\
\text { Combined }\end{array}$ & $0.85 \ddagger(9)$ & $0.81 \ddagger(9)$ & $0.85 \ddagger \quad(9)$ & $0.81 \dagger(8)$ & $0.09(9)$ \\
\hline Triglyceride & $\begin{array}{l}\text { Group I } \\
\text { Group II } \\
\text { Combined }\end{array}$ & $\begin{array}{ll}0.16 & (10) \\
0.61 & (10) \\
0.41 & \end{array}$ & $\begin{array}{ll}0.19 & (10) \\
0.36 & (10) \\
0.28 & \end{array}$ & $\begin{array}{ll}0.18 & (10) \\
0.51 & (10) \\
0.35 & \end{array}$ & $-0.04 \quad(9)$ & $\begin{array}{c}0.73 \dagger(10) \\
-0.21 \\
0.35\end{array}$ \\
\hline
\end{tabular}

* Figures in parentheses indicate the number of observations.

$\dagger$ Significant at 0.05 .

\pm Significant at 0.01 
correlates positively with the free, esterified, and total cholesterols and phospholipid of the intima. The triglyceride of the fatty streak does not correlate with any intimal lipid, nor does the triglyceride of the intima correlate with any lipid of the fatty streak.

\section{Discussion}

Selection of aortas may influence the results and yield conclusions that are unknowingly dependent upon the selection of the cases. Despite the potentially important differences in the two series of subjects of this study, such as the differences in the extent of intimal surface involved with lesions and the differences in lipid content and relative proportions of the lipids, the pattern of correlations among the lipids was similar. This suggests that these findings may possibly be applicable to the general population since the factors that differentiated the groups apparently had no effect. Only the fundamental difference in the pattern of the correlation between age and lipids, particularly cholesterol, appeared to distinguish the groups. Smith reported a positive correlation of 0.83 between ester cholesterol of normal intima and age (5). Buck and Rossiter (14) reported correlation between age and cholesterol and phospholipid. Examination of their data suggests, however, that the effect of aging seems to have occurred primarily in the first 2 decades and after 50 years.

The validity of comparing these tissue specimens does not appear to have been compromised by contamination of the specimens of normal and diseased intima with medial fibers and those of the fatty streak with normal intimal tissue. Significant differences in lipids were demonstrated among these three tissues in both groups of aortas. If significant contamination of normal and fatty streaked intima by media had occurred, the correlations between the lipid contents of the normal and fatty streaked intima and those of the media would be expected to be positive and frequently significant. The latter was not observed. Also, the per cent of cholesterol esterified was, with one exception, regularly higher in the intima than in the media, which would not have been expected if contamination of intima by media had been appreciable.

The dominance of cholesterol in the more advanced atherosclerotic lesions has been reported by numerous investigators, whereas its role in the earlier gross fatty streak lesions has received limited attention. Cholesterol clearly dominates the lipids accumulated in these lesions, also. Smith reported the cholesterol of isolated fatty streaks to average $40 \%$ of the total lipids with a high of $58 \%$ and later indicated that ester cholesterol alone may comprise up to $60 \%$ of total lipids (3, $15)$. In our group I aortas, cholesterol and cholesterol esters constituted $47 \%$ of the normal intimal lipids compared to $81 \%$ of the lipids in the fatty streak through the accumulation of both forms of cholesterol. Further study will be needed to determine if proportionately more ester accumulates in the less severe fatty streak lesions, since almost equal proportions of the two forms accumulate in the more severe of these lesions. Our phospholipid data agree with those of Smith, who noted that the total phospholipid increased in the fatty streak (3) but to a lesser extent than the cholesterol.

There is no evidence in the present study that triglyceride accumulates in the fatty streak. This has not previously been studied within single arteries. Published data on disease and arterial triglyceride are inconclusive. They report values for fatty streaks similar to (16) or increased from $(5,14,17)$ those for the normal intima. Data on more advanced lesions are also conflicting, as they note both no change $(17,18)$ and an increase $(5$, $15,16)$. These conflicts probably reflect the differences in technique that prevent rigorous comparisons among the studies. Further investigation is needed to clarify the role of triglyceride, particularly in the more advanced lesions. Triglyceride is of particular interest since its concentration in serum has been proposed as a discriminating measure of the risk of clinically manifest atherosclerosis (19).

The intimal tissues and their cholesterol demonstrate several relationships. The grossly normal intimae had a total cholesterol content ranging from 1.1 to $8.7 \mathrm{mg}$ per $\mathrm{g}$ of tissue, and they demonstrated upon microscopic examination the accumulation of droplets of lipid. This suggests that the intima has a large capacity for accumulating cholesterol before grossly visible pathological changes occur. Since the highest intimal total cholesterol we have observed in another study was $9.6 \mathrm{mg}$ per $\mathrm{g}$ and the lowest fatty streak total cholesterol was 
$9.6 \mathrm{mg}$ per $\mathrm{g}$, the intima appears to have a threshold value for cholesterol concentration of about $10 \mathrm{mg}$ per $\mathrm{g}$ which, when exceeded, is accompanied by the development of a gross fatty streak. This estimate of the threshold concentration is likely to be low, since we have measured the average concentration in tissue samples comprised of both normal and abnormal cells. The concept of a threshold requires that once the critical level of cholesterol is exceeded some major alteration in morphology of the intima occurs. On the basis of gross examination, this appears to be a local thickening of the intima, which raises the endothelial surface above its surroundings and is accompanied by the appearance of grossly visible fat accumulation. There does not appear to be a similar threshold concentration for the total phospholipid. The concentration of cholesterol in the fatty streak tissue ranged widely from 9.6 to $74.5 \mathrm{mg}$ per $\mathrm{g}$ of tissue. This wide range of values reflects the probable wide variation of fat infiltration among lesions.

Comparison of the normal intima with its adjacent normal media, while showing similar contents of total cholesterol, indicates that in the intima a greater proportion is esterified, which confirms the difference first reported by Smith (3). The high per cent of esterified cholesterol in the intima is unusual among human tissues, being exceeded in healthy tissue only in the plasma (70\% esterified) and in the adrenal cortex (up to $80 \%$ esterified) (20). The medial phospholipid con- tent is significantly higher and the triglyceride content lower than that of the intima. The media would appear to be quite different from the intima in the metabolism of each of the major lipids, since it has different lipid contents, a different pattern of interlipid correlation, and lacks correlation between its lipids and those of other tissue. Perhaps these differences in lipids may relate to the differences in environment and cellular metabolic process and may determine the medial resistance to developing atherosclerosis.

Analysis by correlation coefficient of the intimal content of the various lipids indicates a characteristic pattern of interlipid association that is disrupted in the fatty streak lesions. These are summarized in Figure 1 using the average lipid concentration of group I aortas and the significant combined correlations of the two series. The tissue lipids are represented by circles whose areas are proportional to their concentrations. Significant differences between concentrations are indicated by different sized circles. Positive interlipid correlations (significant at $p<0.01$, except between intimal and fatty streak phospholipid, $\mathrm{p}<$ 0.05 ) are indicated by solid bars for lipids within a tissue, by continuous lines for the same lipids in different tissues, and by dashed lines for different lipids in different tissues. Thus, the three major lipids of intima are positively intercorrelated, whereas the triglyceride content is minor and lacks any correlation. The fatty streak shows an increase in phospholipid and in the cholesterols,

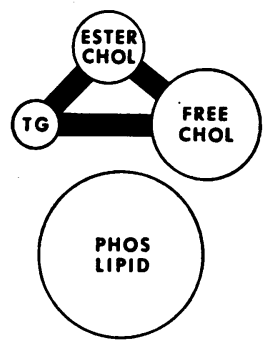

NORMAL MEDIA

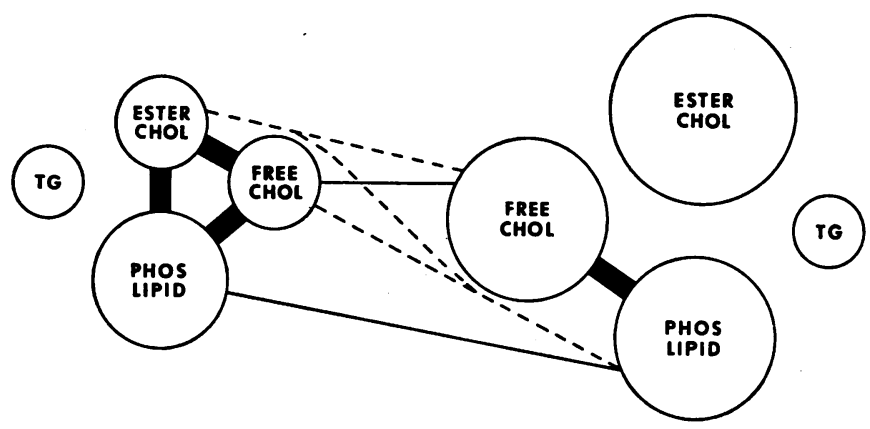

NORMAL INTIMA
FATTY STREAKED

INTIMA

Fig. 1. RELATIVE LIPID CONCENTRATIONS AND PATteRNS OF SIGNIFICANT INTERLiPid CORRELATION IN TISSUES OF THE hUMAN THORACIC AORTA. Free chol. = free cholesterol, ester. chol. = esterified cholesterol, phos. lipid $=$ phospholipid, and $T G=$ triglyceride. See Discussion for further explanation. 
especially marked in ester cholesterol, with the latter lacking correlation with any other lipid. Yet, the fatty streaks retain vestiges of the pattern of correlation seen in the normal intimae, i.e., the correlation between free cholesterol and phospholipid, and remain closely linked to the normal intimae, i.e., the correlation of their free cholesterol and phospholipid with the cholesterols and phospholipid of the normal intimae.

Hypothetical mechanisms may be proposed to explain the differences in patterns of lipid correlation between normal intima and fatty streaked intima. A significant correlation between the tissue concentrations of two lipids may indicate that their metabolic pathways are closely linked. The accumulation of ester cholesterol in the fatty streak without the close interlipid associations seen in the normal intima may be due to intimal tissue losing control over the quantity of cholesterol it acquires, or it may be due to disruption of its mechanisms for handling cholesterol. In view of the present data, the latter could be caused by failure of the cell mechanism linking esterified and free cholesterol, as a fatty acid transferase (21), or by isolation of esterified cholesterol from the normal cellular mechanisms by segregation into different forms of intracellular vacuoles and extracellular lipid $(6,22)$. These phenomena would appear to proceed independently of triglyceride metabolism.

The technique of describing tissue lipids employed here may be of value in further studies of the pathogenesis of atherosclerosis. The changes preceding the formation of the gross fatty streak and those accompanying the conversion of fatty streaks to fibrous plaques could be examined in more detail and related to the detailed morphological alterations in lipids observed with the electron microscope. Comparison of arteries from populations having various degrees of atherosclerosis may reveal chemical differences indicative of differences of metabolism. The technique could also be used to further evaluate the similarity of atherosclerosis in man with that experimentally induced in other animal species and to describe the effects of potential therapeutic agents.

\section{Summary}

A comparative study has been made among the concentrations of free and ester cholesterol, total phospholipid, and triglyceride in the grossly normal media, grossly normal intima, and fatty streaked intima of the thoracic aorta from 21 individuals aged 25 to 63 years. The content of lipid of the fatty streaks, when compared to the adjacent normal intimae, averaged for cholesterol about $500 \%$ higher and for phospholipid about $45 \%$ higher but for triglyceride showed no difference. Triglyceride accumulation did not appear essential for the formation of the gross fatty streak. The intimal content of cholesterol appeared to have a threshold value of about $10 \mathrm{mg}$ per $\mathrm{g}$ at which gross fatty streaks formed. The mediae were different from the intimae in the concentrations of their lipids. Each tissue had a unique pattern of significant correlations among the concentrations of its lipids. In the fatty streaked intima the pattern of correlation resembled in part that of the normal intima, and some of its lipids correlated significantly with the lipids of the adjacent normal intima. The comparative analysis of lipid content in the separate normal tissues and lesions within individual arteries and the evaluation of associations among these lipids are promising methods for investigating the role of lipids in the pathogenesis of human atherosclerosis.

\section{Acknowledgments}

We wish to acknowledge the generous aid of the Department of Pathology of Western Reserve University for the procurement and histological preparation of tissue specimens and the excellent technical assistance of Mrs. Erica Wetzler and Mrs. Barbara Weissinger.

\section{References}

1. Holman, R. L., H. C. McGill, Jr., J. P. Strong, and J. C: Geer. The natural history of atherosclerosis: the early aortic lesions as seen in New Orleans in the middle of the 20th century. Amer. J. Path. 1958, 34, 209.

2. Robertson, W. B., J. C. Geer, J. P. Strong, and H. C. McGill, Jr. The fate of the fatty streak: Exp. Molec. Path. 1963, 1 (suppl.), 28.

3. Smith, E. B. Intimal and medial lipids in human aortas. Lancet 1960, 1, 799.

4. Nelson, W. R., N. T. Werthessen, R. L. Holman, H. Hadaway, and A. T. James. Changes in fatty-acid composition of human aorta associated with fatty streaking. Lancet 1961, 1, 86.

5. Smith, E. B. The influence of age and atherosclerosis on the chemistry of aortic intima. I. The lipids. J. Atheroscler. Res. 1965, 5, 224.

6. Geer, J. E., and M. A. Guidry. Cholesterol ester composition and morphology of human normal in- 
tima and fatty streaks. Exp. Molec. Path. 1964, $3,485$.

7. Lyngborg, K., and W. Insull. Unpublished data.

8. Horning, M. G., E. A. Williams, and E. C. Horning. Separation of tissue cholesterol esters and triglycerides by silicic acid chromatography. J. Lipid Res. $1960,1,482$.

9. Carroll, K. K. Separation of lipid classes by chromatography on Florisil. J. Lipid Res. 1961, 2, 135.

10. Abell, L. L., B. B. Levy, B. B. Brodie, and F. E. Kendall. A simplified method for the estimation of total cholesterol in serum and demonstration of its specificity. J. biol. Chem. 1953, 195, 357.

11. Carlson, L. A., and L. B. Wadström. Determination of glycerides in blood serum. Clin. chim. Acta 1959, 4, 197.

12. Bartlett, G. R. Phosphorus assay in column chromatography. J. biol. Chem. 1959, 234, 466.

13. Snedecor, G. W. Statistical Methods. Ames, Iowa State University Press, 1956, p. 77.

14. Buck, R. C., and R. J. Rossiter. Lipids of normal and atherosclerotic aortas. Arch. Path. 1951, 51, 224.

15. Smith, E. B. The effects of age and of early atheromata on the intimal lipids in men. Biochem. $\mathrm{J}$. 1962, 85, 49 P.
16. Böttcher, C. J. F., F. P. Woodford, C. C. Ter Haar Romeny-Wachter, E. Boelsma-Van Houte, and C. M. Van Gent. Fatty-acid distribution in lipids of the aortic wall. Lancet 1960, 1, 1378.

17. Mead, J. F., and M. L. Gouze. Alterations in aorta lipids with advancing atherosclerosis. Proc. Soc. exp. Biol. (N. Y.) 1961, 106, 4.

18. Whitehead, T. P., M. K. Alexander, D. F. Barrowcliff, A. P. Prior, and N. Marsh. Lipid and mineral matter in coronary arteries and aorta I. Results in a group of men dying from causes unrelated to coronary artery disease. J. Atheroscler. Res. 1962, 2, 199.

19. Albrink, M. J., J. W. Meigs, and E. B. Man. Serum lipids, hypertension and coronary artery disease. Amer. J. Med. 1961, 31, 4.

20. Cook, R. P. Cholesterol. New York, Academic Press, 1958, p. 165.

21. Glomset, J. A. The mechanism of the plasma cholesterol esterification reaction: plasma fatty acid transferase. Biochim. biophys. Acta (Amst.) 1962, 65, 128.

22. Balis, J. U., M. D. Haust, and R. H. More. Electron-microscopic studies in human atherosclerosis. Exp. Molec. Path. 1964, 3, 511. 